\title{
RESPONSABILIDADE CIVIL DE INSTITUIÇÕES FINANCEIRAS POR DANOS SOCIOAMBIENTAIS
}

\section{Luciane Moessa de Souza}

Possui graduação em Direito pela Universidade Federal do Paraná (1995), Mestrado em Direito do Estado pela Universidade Federal do Paraná (2001) e Doutorado em Direito, Estado e Sociedade pela Universidade Federal de Santa Catarina (aprovação com louvor, em 2010), com estágio de pesquisa (Doutorado-sanduíche) no Center for Public Policies Dispute Resolution da Universidade do Texas (campus de Austin). Email: lumoessa@hotmail.com

\section{RESUMO}

O trabalho propõe parâmetros concretos, à luz das normas regulatórias, tanto os de iniciativas autorregulatórias das melhores práticas de mercado (identificadas a partir de pesquisa empírica com instituições financeiras brasileiras e europeias) como os das normas e procedimentos adotados por cada instituição financeira, para definir em que situações e em que medida elas podem ser responsabilizadas por danos sociais ou ambientais causados por empreendimentos por elas financiados, seja mediante concessão de crédito, seja mediante realização de investimentos. Também são examinadas as diversas correntes doutrinárias atualmente existentes sobre o assunto, que buscam definir como objetiva ou subjetiva essa responsabilidade, examinando-se se é possível ou não limitá-la no tempo e se é o caso de admitir-se um regime de solidariedade (e com base em que critérios). Ainda, é analisada a jurisprudência brasileira sobre o tema. Por fim, examina-se se é possível reconhecer sigilo bancário em relação a informações de interesse socioambiental detidas por instituições financeiras com o propósito de realizar análise de riscos desta natureza.

Palavras-chave: Responsabilidade Civil; Instituições Financeiras; Danos Socioambientais; Crédito; Investimentos . 


\title{
CIVIL LIABILITY OF FINANCIAL INSTITUTIONS FOR ENVIRONMENTAL OR SOCIAL DAMAGES
}

\begin{abstract}
This paper proposes criteria to define, considering regulation, selfregulation, market best practices (identified through empirical research with Brazilian and Europeans financial institutions) and their own rules and procedures, in which situations financial institutions may be held liable for damages caused by financed enterprises, either by lending or investment activities. It also examines the various theories on the nature of this liability, which aims to define it as objective or subjective, if it is possible to limit this liability over time, and if it is possible to adopt a system of joint liability. Moreover, it analysis Brazilian courts decisions on the topic. Finally, it examines if it is the case of recognizing bank secrecy in which concerns information with social or environmental relevance produced or gathered by financial institutions with the purpose of assessing these kinds of risks.
\end{abstract}

Key-words: Civil Liability; Financial Institutions; Social or Environmental Damages; Credit; Investments. 


\section{INTRODUÇÃO}

Em primeiro lugar, devo esclarecer a abrangência que dou ao tema no âmbito desse trabalho, distinguindo-a em parte da abordagem feita por outros autores brasileiros (e também alguns europeus) que o examinaram.

Com relação à doutrina estrangeira, esclareço que a exploração realizada no âmbito desta pesquisa não foi de modo algum exauriente inclusive por não estarem presentes em diversos países as peculiaridades da legislação e da jurisprudência mais recente sobre o tema no Brasil. Mesmo entre os autores europeus que examinaram o assunto, o enfoque, em geral, se restringe à descrição da experiência dos EUA, tanto em termos de evolução legislativa quanto jurisprudencial, por ser esse o primeiro país do mundo onde o assunto foi levado ao Judiciário. Ocorre que a judicialização que ocorreu por lá parece estar restrita ao problema dos imóveis oferecidos como garantias imobiliárias que estejam contaminados. Trata-se da repercussão mais evidente da legislação ambiental sobre os bancos, mas, no caso brasileiro, esse tema está bem longe de ser o único que já foi judicializado. Aliás, quanto a esse tema propriamente dito, no caso do Brasil, não há muito o que se discutir, em face da natureza real das obrigações ambientais (como está evidente desde o Código Florestal de 1965, por exemplo, com relação à reserva legal nos imóveis rurais e às áreas de preservação permanente) - elas acompanham o imóvel a cada transferência de propriedade.

O tema mais relevante para o Brasil é, isso sim, a definição dos contornos da responsabilidade civil por dano ambiental causado por empreendimentos financiados - e, nesse sentido, ele já foi examinado por alguns autores desde a pioneira obra de Ana Luci Esteves Grizzi e outras, publicada em 2003.

$\mathrm{O}$ que nenhum autor examinou ainda - e eu pretendo enfocar - é a responsabilidade das instituições financeiras por danos causados por empreendimentos não apenas em razão de financiamentos (operações de crédito nas quais se conhece a destinação do recurso emprestado), mas também nos empréstimos, desde que realizados a pessoas físicas ou jurídicas em razão de atividade empresarial.

Outra inovação da minha abordagem é o fato de que não pretendo me restringir aos danos ambientais - enfoque escolhido por todos os que se detiveram sobre o tema anteriormente, em razão do regime próprio de responsabilidade civil previsto na Lei $n^{\circ}$. 6.938, de 1981. A razão para essa 
escolha é simples e qualquer estudo que se debruce sobre o tema pode comprovar: boa parte das normas regulatórias (e esse é o caso brasileiro, notadamente com a Resolução do Conselho Monetário Nacional nº . 4.327, de 2014), das normas autorregulatórias e práticas do mercado financeiro tratam as dimensões ambiental e social de forma unívoca ${ }^{1}$ - e essa parece ser a abordagem mais adequada, já que ambos são pilares do Desenvolvimento Sustentável, ao lado da dimensão econômica.

Por fim, esclareço que vou abordar também as operações de investimento. $\mathrm{O}$ único autor brasileiro que já examinou, de forma preliminar, o tema (envolvendo apenas as operações realizadas por bancos de investimentos) foi Rômulo Sampaio, em obra publicada em 2013. Vou partir dessa contribuição inicial e buscar desenvolver o tema.

No que concerne ao risco ambiental propriamente dito, existe uma tendência jurisprudencial de responsabilização solidária e objetiva das instituições financeiras pelos danos causados por empreendimentos financiados. O Superior Tribunal de Justiça tem entendido, em alguns julgados, que a responsabilidade do financiador de empreendimentos com impactos ambientais é objetiva ${ }^{2}$, com esteio no art. $14, \S \S 1^{\circ}$. e $3^{\circ}$, IV, da Lei $\mathrm{n}^{\circ}$. 6.938, de 31 de agosto de 1981. Muito embora, de modo geral, a doutrina sobre o assunto defenda esse posicionamento, há quem adote entendimento diverso, no sentido de que ela deve ser subjetiva.

Vou me posicionar também a respeito desse tema controvertido, buscando detalhar ao máximo meu posicionamento, de modo que seja possível dele extrair todas as possíveis consequências para o adequado funcionamento das instituições financeiras e para a proteção ambiental, à luz dos princípios e normas aplicáveis ao tema no Direito brasileiro, sem deixar de buscar subsídios também nas melhores práticas do mercado nacional e internacional, tomando como referência pesquisade PósDoutorado sobre Sustentabilidade Socioambiental e Sistema Financeiro desenvolvida por Luciane Moessa de Souza ${ }^{3}$.

\footnotetext{
1 No caso do mercado de investimentos, também o tema da governança costuma ser tratado ao lado das questões ambientais e sociais, sendo inclusive consagrado o uso da sigla ESG para "Environmental, Social and Governance".

2 Ver, por exemplo: REsp 1.071.741-SP e REsp 650.728-SC, ambos tendo como Relator o Ministro Herman Benjamin ( $2^{\mathrm{a}}$ Turma). Nestes dois acórdãos, o Ministro relator consignou, ao tratar da solidariedade em matéria de reparação do dano ambiental: "[p]ara o fim de apuração do nexo de causalidade no dano ambiental, equiparam-se: quem faz, quem não faz quando deveria fazer, quem deixa fazer, quem não se importa que façam, quem financia para que façam e quem se beneficia quando outros fazem" (grifei). Ressalte-se que nenhuma instituição financeira era parte na referida ação e que não houve, portanto, condenação nesse sentido.

3 A pesquisa em questão foi desenvolvida entre dezembro de 2014 e abril de 2016, no âmbito da Universidade de São Paulo (USP), sob supervisão da Professora Doutora Ana Maria Nusdeo. Ela incluiu
} 


\section{AS DIFERENTES CORRENTES QUANTO À NATUREZA DA RESPONSABILIDADE DO CAUSADOR INDIRETO DO DANO}

Antes de começar a abordar a natureza da responsabilidade, é preciso esclarecer o conceito de dano ambiental. Adotarei o conceito mais amplo, defendido, entre muitos outros, por Celso Antonio Pacheco Fiorillo (2001, p. 19-22), que inclui, além do meio ambiente natural (proteção à biodiversidade - nela incluídas a fauna e a flora,os recursos hídricos, a qualidade do ar e do solo e a cobertura florestal, instituição de áreas especialmente protegidas, etc); o meio ambiente cultural (de modo que a legislação de proteção ao patrimônio histórico, cultural e paisagístico fica plenamente abrangida); o meio ambiente artificial (conjunto de edificações e equipamentos públicos) e o meio ambiente do trabalho (questões de saúde e segurança dos empregados). A rigor, nenhuma dessas categorias inclui questões de saúde pública em geral, as quais estão, todavia, expressamente abrangidas na proteção ambiental, conforme art. $3^{\circ}$., III, da Lei $n^{\circ} .6 .938$, de 1981. Quanto ao meio ambiente cultural, artificial e urbano, a proteção está consagrada, como lembra Fiorillo, em nível constitucional (arts. 182, 216 e 200, VIII).

Alguns danos, como aqueles causados à cultura das comunidades tradicionais - as quais, como se sabe, convivem em perfeita harmonia com a natureza - oferecem um grau maior de dificuldade de enquadramento: seriam eles danos ambientais ou sociais? A rigor, devem merecer exatamente o mesmo grau de proteção que a cultura dominante, à luz do que prescreve o ordenamento constitucional brasileiro (art. $215^{4}$ ), de modo que a Lei $\mathrm{n}^{\circ} .6 .938$, de 1981, que é anterior ao texto constitucional, deve ser interpretada de uma forma que a harmonize com a Lei Maior, incluindo-se

\footnotetext{
um período em que a autora foi pesquisadora visitante na Università Luigi Bocconi, de Milão, em 2015, durante o qual realizou pesquisa empírica em sete países da Europa Ocidental (Itália, Suíça, Holanda, Alemanha, Reino Unido, Suécia e França) sobre o tema. A metodologia adotada envolvia a aplicação de questionários a dez categorias de entrevistados: a) grandes bancos comerciais; b) bancos de desenvolvimento; c) bancos sociais, éticos ou alternativos; d) bancos de pequeno e médio porte (em geral, cooperativos) italianos; e) reguladores bancários; f) fundos de pensão; g) gestoras de ativos (asset managers); h) instituições do terceiro setor que atuam na matéria; i) organizações internacionais que atuam na matéria; j) consultorias especializadas que atuam no tema. Idêntica metodologia foi aplicada no Brasil.

4 “Art. 215. O Estado garantirá a todos o pleno exercício dos direitos culturais e acesso às fontes da cultura nacional, e apoiará e incentivará a valorização e a difusão das manifestações culturais.

$\S 1^{\circ} \mathrm{O}$ Estado protegerá as manifestações das culturas populares, indígenas e afro-brasileiras, e das de outros grupos participantes do processo civilizatório nacional."

Além disso, o art. 231 reconhece aos indígenas o direito de ocuparem permanentemente suas terras e de vê-las demarcadas e o art. 68 do ADCT reconhece idêntico direito às comunidades de descendentes de quilombolas.
} 
também a proteção a comunidades tradicionais.

Nunca é demais lembrar o art. 170 da Constituição Federal, que trazalguns princípios fundamentais da Ordem Econômica. Esta, "fundada na valorização do trabalho humano e na livre iniciativa, tem por fim assegurar a todos existência digna, conforme os ditames da justiça social", entre outros:
V - defesa do consumidor;
VI - defesa do meio ambiente, inclusive mediante tratamento diferenciado conforme o impacto ambiental dos produtos e serviços e de seus processos de elaboração e prestação (redação dada pela Emenda Constitucional n ${ }^{\circ} 42$, de 2003)

Ainda, o art. 192 dispôs que "[o] sistema financeiro nacional [será] estruturado de forma a promover o desenvolvimento equilibrado do País e a servir aos interesses da coletividade, em todas as partes que o compõem" (redação dada pela Emenda Constitucional no 40, de 2003).

No caso do dano puramente social (por exemplo, aquele causado à coletividade de consumidores, mas que não envolva questões de saúde pública), não há dúvida de que não cabe a aplicação da legislação ambiental, por haver legislação própria estabelecendo um outro regime de proteção (muito embora existam diversos pontos de contato, inclusive por ter sido justamente o Código de Defesa do Consumidor a primeira norma que conceituou as diferentes categorias de direitos coletivos).

A relevância dessa discussão se estabelece por ter a Lei n ${ }^{\circ} .6 .938$, de 1981, previsto um regime de responsabilidade civil objetiva ${ }^{5}$ para o causador do dano ambiental ( $\operatorname{art} .14, \S 1^{\circ}$.), seja ele o poluidor direto ou indireto (cf. conceito do art. $3^{\circ}$., IV). A instituição financeira que concede crédito a empreendimento poluente, evidentemente, somente pode ser considerada causadora indireta do dano ambiental - e quanto a isso não há qualquer dissenso doutrinário. A controvérsia reside, de fato, em saber se existe um regime jurídico distinto para o poluidor direto e para o poluidor indireto, como defende Rômulo Sampaio (2013) ou se o regime jurídico é

\footnotetext{
5 Trata-se de concretização do princípio do poluidor pagador. Dal Maso relata (2001, p. 39) que regras semelhantes (regime de responsabilidade civil objetiva por danos ambientais) existem em vários países da União Europeia, sendo que alguns países, entretanto, (como a Itália e a Dinamarca), limitam a responsabilidade objetiva para algumas situações específicas de atividades especialmente perigosas para o meio ambiente. Os primeiros países que criaram um regime de responsabilidade civil específico para os danos ambientais, segundo ele, foram os escandinavos, seguidos pela Alemanha e pela Áustria. Já em 1992, a Convenção de Lugano em matéria de Responsabilidade Civil por Danos Ambientais causados por Atividades Perigosas, editada pelo Conselho da União Europeia, estabeleceu um regime de responsabilidade objetiva para os danos dessa natureza.
} 
idêntico, como defende Alexandre Raslan (2012).

Considerando-se tanto aqueles que, como Raslan, defendem regime jurídico único, quanto aqueles que definem o regime jurídico distinto, é possível identificar, de plano, diversas correntes:

a) a que, além de entender ser a responsabilidade do financiador também objetiva, adota a teoria do risco integral e não aceita a possibilidade de incidência de caso fortuito e força maior como excludente de responsabilidade, como afirma Alexandre Raslan; outra possível excludente é o fato de terceiro, sobre o qual ele não se pronuncia; mas, há outros autores que defendem a teoria do risco integral, como Annelise Steigleder, citada por Nusdeo ${ }^{6}$ e Raslan, admite);

b) a que admite ser a responsabilidade do financiador também objetiva, porém, admitindo-se algumas excludentes de responsabilidade (e afastando, portanto, a teoria do risco integral), como aponta Paulo Affonso Leme Machado ${ }^{7}$;

c) a que, em tese, admite ser a responsabilidade do financiador também objetiva, porém, admite plena incidência das excludentes de responsabilidade e, além disso, entende que deve haver violação de um dever, adotando a teoria do risco criado, como Ana Luci Esteves Grizzi e outras (2003, p. 27) e Rômulo Sampaio.

Deve-se ressaltar, porém, que a "teoria do risco criado" produz efeitos absolutamente semelhantes ao reconhecimento de uma responsabilidade de natureza subjetiva, pois pressupõe a violação de um dever legal - portanto, culpa, ainda que por mera omissão.

Veja-se, por exemplo, a posição de Ana Luci Esteves Grizzi e outras (2003, p. 36):

[...] o financiador [...] tem o dever de, inicialmente, exigir a apresentação de documentação necessária, o que, no caso em tela, corresponde às licenças, para, só assim, depois de constatada a regularidade junto aos critérios preestabelecidos, conceder o financiamento, sem, contudo, deixar de controlar as atividades do financiado, sob pena de ser responsabilizado integralmente pelos danos por ele 6 NUSDEO, Ana Maria de Oliveira. Instituições financeiras e danos ambientais causados por atividades financiadas. YOSHIDA, Consuelo; PIAZZON, Renata; KISHI, Sandra; VIANNA, Marcelo Drügg Barreto (coord.). Finanças Sustentáveis e Responsabilidade socioambiental das instituições financeiras. Belo Horizonte: Fórum, 2017, p. 29.

7 Para Paulo Affonso Leme Machado, “[...] ainda que a corresponsabilidade não esteja expressamente definida nessa lei, parece-nos que ela está implícita. A alocação de recursos do financiador para o financiado, com a transgressão induvidosa da lei, coloca o financiador numa atividade de cooperação ou de coautoria com o financiado em todos os atos lesivos ambientais que ele fizer, por ação ou omissão.” (2004, p. 306). Quanto às excludentes de responsabilidade, defende ele que os fatos da natureza (força maior) podem afastar a responsabilidade do agente se, no caso concreto, este demonstrar que o fenômeno natural não poderia ser evitado ou impedido, porém, sem se levar em conta a diligência do agente (Direito Ambiental Brasileiro. São Paulo: Malheiros, 2015, p. 420-421). 
causados.

\subsection{Responsabilidade objetiva e comprovação de nexo de causalidade}

Outro posicionamento cujos efeitos são idênticos ao terceiro visto acima (teoria do risco criado) é o defendido, entre outros autores, pela Professora Ana Maria Nusdeo (2017, p. 42), o qual, embora defenda também ser a responsabilidade do causador indireto do dano ambiental de natureza objetiva (em face da redação do texto legal), entende que deve haver a prova do nexo de causalidade. Para ela, diante da existência de "concausas" (diferentes causas que concorreram para o dano), seria preciso indicar qual foi a norma violada pelo financiador.

Por outro lado, assevera ela, com base na redação do art. 225 da Constituição Federal, existir "um dever constitucional de que cada um, indivíduos, associações e empresas adotem as práticas ao seu alcance para a consecução do objetivo da preservação ambiental" $(2017 \text {, p. } 35)^{8}$ - o que representa nada mais que uma concretização dos princípios da prevenção e da precaução (in dubio pro ambiente).

Ela propõe, para que se comprovem a existência do nexo de causalidade e a ocorrência do dano ambiental, seja adotada a "teoria do escopo da norma violada", que tem como ponto de partida (2017, p. 31):

[...] a norma jurídica cuja violação ensejou a ocorrência do dano. O método de aplicação dessa teoria consiste em, numa dada hipótese de dano, identificar como sua causa aquela sem a qual o dano não teria se verificado (causa sine qua non), numa análise naturalística e material de causalidade. Identificadas as potenciais causas do dano, deverão ser analisadas as condutas, agora do ponto de vista jurídico. Isto é, [cabe] encontrar a resposta para a pergunta: alguma das condutas, no rol de causas sine qua non, é proibida por determinada norma? Ou, em outras palavras, a conduta que levou potencialmente ao dano ingressou no âmbito do escopo da norma violada? Se a resposta for afirmativa, aí se encontra a causa do dano, naturalística e juridicamente determinada.

O risco da adoção de tal entendimento no que se refere às instituições financeiras é o de sempre se poder alegar que o crédito ou investimento poderia ter sido obtido junto a outras fontes. Veja-se que Ana

8 Entende ela, porém, que "esse amplo mandamento constitucional que impõe envidar esforços para a preservação do meio ambiente não é apto, por si só, a gerar responsabilidade civil por danos ao meio ambiente aos agentes da coletividade." (2017, p. 12) 
Luci Grizzi e outras afirmam: "O financiamento deve ser imprescindível para o desenvolvimento da atividade degradante" (2003, p. 51).

Por outro lado, é relevante a observação de tais autoras no que concerne à inversão do ônus da prova de demonstrar o nexo de causalidade, de modo que "o demandado é quem teria que provar que não possui qualquer ligação de causalidade com o dano ocorrido" (2003, p. 50).

Mais adiante, Nusdeo reforça seu posicionamento de forma sintética: "deve-se atentar para a importância da existência do nexo de causalidade entre a violação de um dever legal - claramente caracterizada - e o dano." (2017, p. 34). Por aí já se vê que o elemento essencial para a autora são a previsão de dever legal e a existência de sua violação no caso concreto.

Esse entendimento soa bastante apropriado e exato - e é por isso que entendo que não se trata de mera existência de nexo de causalidade e sim de responsabilidade subjetiva. Nos itens seguintes, passo a definir os elementos para análise da culpa em situações concretas, à luz tanto do regime geral da responsabilidade civil quanto das normas regulatórias existentes sobre o assunto e das práticas de mercado.

\subsection{Responsabilidade subjetiva por omissão}

Outro elemento muito interessante que pode ser colhido das lições da Prof ${ }^{a}$. Ana Maria Nusdeo diz respeito à coincidência de regime de responsabilidade do causador indireto do dano ambiental nas situações em que: a) o Poder Público se omite no exercício do poder de polícia; b) as instituições financeiras se omitem de cumprir seus deveres previstos em normas legais ou regulamentares.

De fato, o regime deve ser absolutamente idêntico. O que se nota é que, em ambos os casos, a responsabilidade se dá por omissão e não por ação. É por essa razão que é preciso ir além da mera interpretação literal do art. $14, \S 1^{\circ}$., da Lei $n^{\circ} .6 .938$, de 1981, e reconhecer que o regime de responsabilidade não pode ser outro que não o da responsabilidade subjetiva ou decorrente de culpa. Essa discussão já foi amplamente travada no âmbito da responsabilidade civil dos entes públicos, prevista no art. 37, $\S 6^{\circ} \mathrm{da}$ Constituição Federal, não havendo consenso doutrinário sobre o tema ${ }^{9}$.

9 Romeu Felipe Bacellar faz breve inventário a respeito: Celso Antonio Bandeira de Mello, Jacinto de Arruda Câmara, Lúcia Valle Figueiredo e Diogo de Figueiredo Moreira Neto defendem que se trata de responsabilidade subjetiva da Administração Pública. Já Toshio Mukai, Cármen Lúcia Antunes Rocha, 
No mesmo sentido, o entendimento de Dionis Blank e Maria Claudia Crespo Brauner:

[...] é possível estabelecer que é solidária e subjetiva a responsabilidade dos bancos por riscos ambientais causados pelas empresas financiadas, não bastando, para a responsabilização do banco, o simples fato de ter financiado o empreendimento. Essa responsabilidade apenas será reconhecida se restar comprovada a falta de exigência dos requisitos legais para conceder o financiamento ou diante da ocorrência de algum ato de gestão do banco que implique na sua participação no processo decisório da empresa. (2009, p. 272)

Não reconhecer tal circunstância (a necessidade de existência de culpa) seria considerar todas as omissões de poluidores indiretos juridicamente relevantes - o que seria demasiado amplo, gerador de incerteza e até mesmo desestimulador de comportamentos mais cautelosos, pois, se o risco assumido for independente do grau de cautela adotado, passa a não ser compensador incorporar os custos de ser diligente.

Passo a descrever, assim, o que se entende por culpa de instituição financeira, de forma a se reconhecer o dever de reparar danos ambientais (e também sociais) decorrentes de empreendimentos que delas tenham tomado crédito ou obtido investimentos.

\section{PROPOSTA DE RESPONSABILIDADE SUBJETIVA AMPLIADA}

Os delineamentos que passo a propor para que se reconheça a presença (ou não) de culpa da instituição financeira que concedeu crédito ou viabilizou investimentos no empreendimento se baseiam, de um lado, no princípio da prevenção no Direito Ambiental, que, a meu ver, se dirige a todos os integrantes da coletividade (cf. art. 225 da Lei Maior), e, de outro, nos deveres de natureza prudencial já estabelecidos em normas legais e regulamentares brasileiras a respeito do gerenciamento de riscos socioambientais, sobretudo os decorrentes dos impactos indiretos das atividades financiadas pelos agentes financeiros.

Odete Medauar e Weida Zancaner entendem que se trata de responsabilidade objetiva (Direito Administrativo e o novo Código Civil. Belo Horizonte: Editora Fórum, 2007, p. 216-217). 


\title{
2.1 Relevância das normas constitucionais, legais e regulamentares do sistema financeiro
}

\author{
É consequência elementar do princípio da prevenção o dever de
} cautela em qualquer processo decisório no qual estejam presentes riscos de natureza socioambiental.

Além disso, vigoram no Direito brasileiro diversas normas, de nível legal (algumas destas descritas no item 2 acima ${ }^{10}$ ) e infralegal ${ }^{11}$, que trazem obrigações cujo grau de especificidade é bastante variável, para o gerenciamento de riscos socioambientais decorrentes das operações de instituições financeiras. Quando se estiver diante de hipótese clara de violação de norma, não há qualquer questionamento possível quanto à responsabilidade da instituição financeira que financiou o empreendimento que causou o dano ambiental.

10 Outras são, por exemplo, a Lei 8.171, de 1991 (art. 50, § $3^{\circ}$., que dispõe que "[a] aprovação do crédito rural levará sempre em conta o zoneamento agroecológico"); a Lei 11.105, de 24 de março de 2005 (art. $2^{\circ}$., que repetiu dispositivo que já constava da Lei 8.974, de 5 de janeiro de 1995, que trazia a Política Nacional de Biossegurança); a Lei 9.605, de 1998 (art. 72, § 8 . IV), que inclui entre as sanções restritivas de direito decorrentes de infrações administrativas ambientais a "perda ou suspensão da participação em linhas de financiamento em estabelecimentos oficiais de crédito", e a Lei 12.305, de 22 de agosto de 2010 (arts. 16 e 18), a Lei 12.651, de 2012 (art. 78-A), que veda a concessão de crédito rural a proprietários de imóveis não inscritos no Cadastro Ambiental Rural (criado pelo art. 29 da mesma lei - novo Código Florestal).

11 São elas, no caso brasileiro: Decreto 99.274, de 6 de junho de 1990 (art. 19, § 3º); Portaria 1.150, de 18 de novembro de 2003, do Ministério da Integração Nacional(que determinou se recomendasse aos agentes financeiros que se abstivessem de conceder financiamentos ou qualquer outro tipo de assistência com recursos sob a supervisão do referido Ministério para as pessoas físicas e jurídicas que integrassem a Lista Suja do Trabalho Escravo, elaborada pelo Ministério do Trabalho e Emprego); Decreto 6.321, de 21 de dezembro de 2007 (art. 11, que estabelece obrigação de os bancos e agências oficiais federais não concederem crédito de qualquer espécie para empreendimentos cujas atividades se desenvolvam em áreas embargadas por órgãos ambientais em razão de desmatamento ilegal ou que adquiram, transportem ou comercializem produtos oriundos destas áreas); Resoluções do Conselho Monetário Nacional (CMN) 3.545, de 2008 (com redação alterada pela 4.422, de 2015 - que proibiu a concessão de crédito rural a propriedades localizadas na Amazônia Legal que estejam violando a legislação ambiental); 3.813 e 3.814, de 2009 (que vedam o financiamento da produção se esta ocorrer em terras indígenas, nos biomas Amazônia, Pantanal ou Bacia do Alto Paraguai, em áreas com declividade superior a $12 \%$ ou ocupadas com cobertura de vegetação nativa ou reflorestamento, remanescentes florestais, áreas de proteção ambiental, dunas, mangues, escarpas e afloramentos de rocha, áreas urbanas e de mineração); 3.876, de 2010 (que proíbe a concessão de crédito rural a empregadores que figurem na "Lista Suja do Trabalho Escravo"), 4.427, de 2017 (que autorizou a utilização de tecnologias de sensoriamento remoto para fins de fiscalização de operações de crédito rural e, para viabilizar tal procedimento, instituiu uma nova obrigação para os tomadores de crédito rural, a ser obrigatoriamente exigida no momento da contratação, qual seja, de informar-se as coordenadas geodésicas do empreendimento financiado, seja nas operações de crédito de custeio agrícola, seja nas operações de crédito de investimento; 4.327, de 25 de abril de 2014 (que exige de todas as instituições fiscalizadas pelo Banco Central do Brasil o estabelecimento e implementação de uma Política de Responsabilidade Socioambiental e respectivo plano de ação) e, por fim, 4.661 , de 25 de maio de 2018 (art. 10, $\S 4^{\circ}$., que dispõe que as entidades fechadas de previdência complementar devem considerar, na análise de riscos de seus investimentos, sempre que possível, aspectos relacionados à sustentabilidade ambiental, social e de governança). 
Entretanto, na prática, muitas situações haverá em que será necessária uma análise cuidadosa das circunstâncias fáticas para definir se a instituição financeira se desincumbiu ou não de forma adequada dos deveres a ela atribuídos por normas cuja redação é aberta, ensejando eventuais dificuldades no momento da aplicação. Por isso, será necessário também, sem dúvida, examinar outros elementos relevantes, como os compromissos publicamente assumidos pela instituição financeira, os seus procedimentos internos e os graus de diligência e prudência adotados no caso concreto. Abordarei cada um desses pontos após examinar as operações de crédito em que a disponibilidade de informações para a instituição financeira é menor quanto à utilização dos recursos: as operações de empréstimo, leasing e outras similares, quando destinadas a empreendimentos com fins de lucro - excluídas, portanto, tanto operações com consumidores finais pessoas físicas quanto operações com entidades do terceiro setor (as quais, ademais, sequer necessitam de licenciamento ambiental, porquanto oferecem risco socioambiental baixíssimo, já que sua atuação busca, ao contrário, promover impactos positivos).

\subsection{Operações de empréstimo, arrendamento mercantil (leasing) e similares}

No caso de operações de crédito em que os recursos financeiros (ou mesmo o bem adquirido, como nos financiamentos ou leasing de veículos ou outros equipamentos) não se destinam a uma finalidade específica, como no caso de empréstimos de capital de giro, certamente o nível de diligência que haverá de ser exigido da instituição financeira é muito menor, de modo que o risco de sua responsabilização é também proporcionalmente menor.

Isso não significa, entretanto, que, quando se tratar de operações firmadas com pessoas jurídicas com fins lucrativos, nas quais não se pode supor que a utilização será outra que não o desenvolvimento regular de suas atividades, um grau mínimo de diligência não deva estar presente. Nada impede que seja verificada pela instituição financeira, por exemplo, a existência de licenciamento ambiental vigente (quando o setor em que o empreendimento financiado opera requer o licenciamento) e/ou que sejam verificados a existência, número e natureza de eventuais autuações por infrações ambientais e trabalhistas.

Essa verificação periódica, inclusive, é comumente realizada 
por bancos de grande porte, seja no Brasil, seja, por exemplo, na Europa Ocidental ${ }^{12}$. Conceder qualquer modalidade de empréstimo, de qualquer valor, para uma empresa que esteja operando sem licença ambiental vigente ou que tenha grande número de autos de infrações ambientais e trabalhistas é, sem dúvida, temerário e não corresponde ao grau de diligência que se deve esperar de uma instituição financeira minimamente responsável.

Ressalte-se que não se trata aqui de impossibilidade de verificação da utilização dos recursos emprestados; se a empresa está operando irregularmente, ela não deveria estar obtendo crédito de qualquer natureza.

Não tendo sido realizada essa verificação básica, naturalmente, a instituição financeira corre o risco de ser corresponsabilizada pelos danos sociais ou ambientais decorrentes da atividade.

Entendo, porém, que, não sendo identificável a destinação específica dos recursos, no caso de empréstimo, o valor de eventual indenização de responsabilidade da instituição financeira deve ser limitado ao montante envolvido na operação.

\subsection{Relevância da acessibilidade de informações de responsabilidade de órgãos reguladores socioambientais}

O grau de disponibilidade das informações a serem fornecidas por reguladores sociais ou ambientais, assim como o grau de diligência empregado pela instituição financeira nessa busca, é outro elemento essencial. Deve o banco buscar as informações publicamente disponíveis e examiná-las com a atenção necessária, sobretudo em caso de setores com maiores riscos socioambientais. Como sustenta Rômulo Sampaio, existe um "dever de cuidado" em relação à posição do responsável direto por eventual dano ambiental, já reconhecido inclusive em alguns julgados (2013, p. 29)

O que a instituição financeira não pode é desempenhar o papel que corresponde aos órgãos reguladores ambientais e sociais. Como ressalta Ana Maria Nusdeo, "incumbe ao Poder Público o exercício do poderdever de fiscalização e imposição de penalidades, relativas ao seu poder de polícia. A solicitação desses documentos pela instituição financeira não

\footnotetext{
12 Para uma descrição detalhada a respeito, baseada em farta pesquisa empírica realizada com instituições financeiras que atuam no Brasil e em seis países da Europa Ocidental, ver: SOUZA, Luciane Moessa de. Sustentabilidade socioambiental no sistema financeiro: diagnóstico e propostas. Relatório de Pesquisa de Pós-Doutorado. Universidade de São Paulo (USP), abril de 2016.
} 
tem o condão de evitar o dano ambiental." (2017, p. 38).

Ou seja, em países onde a efetividade do poder de polícia é deficiente, como é o caso do Brasil, é evidente que não se pode esperar que um ente do sistema financeiro vá se substituir ao órgão ambiental, que é quem tem a expertise necessária para fiscalizar a regularidade ambiental de empreendimentos. A mesma autora anota, com propriedade: "não há parâmetros adequados para um controle por agente que não detém poder de polícia. Dentro de certos parâmetros legais, porém, algum monitoramento por parte da instituição é viável.” (2017, p. 41). Idênticas ponderações são realizadas por Blank e Brauner: "não se pode exigir do banco um controle técnico acerca dos índices de poluição ou sobre a regularidade das licenças expedidas pelos órgãos técnicos competentes." (2009, p. 269). Não se esqueça, todavia, de que, a depender do grau de risco ambiental da operação, pode ser conveniente para o próprio banco (em razão do elevado risco de crédito) contratar uma empresa especializada em auditoria ambiental para fazer uma avaliação.

Da mesma forma, verificar se o licenciamento ambiental foi realizado de forma adequada também é algo que excede ao nível da razoabilidade - muito embora o licenciamento seja um dos principais elementos voltados à prevenção de danos ambientais. Mais uma vez, salienta com razão Ana Maria Nusdeo:

[...] um elemento principal [...] é a qualidade e eficácia dos licenciamentos concedidos. Isso porque a contribuição dos estabelecimentos de crédito para a eficácia da norma não substitui o poder-dever da Administração para a constituição dessa eficácia. (2017, p. 36)

Ela cita, porém, o pensamento de Paulo Affonso Leme Machado (2015, p. 394-395), para quem é razoável entender-se que as instituições financeiras, ao menos no caso de financiamentos, devem examinar se está havendo o cumprimento das condicionantes da licença ambiental.

Nesse compasso, quanto ao grau de diligência razoável a ser esperado das instituições financeiras, sempre tendo em conta o setor econômico, o porte da empresa tomadora do crédito ou receptora dos investimentos e até mesmo o valor da operação, assim como o grau de exposição da instituição financeira a cada cliente e a cada setor econômico, propõe-se sejam utilizadas, no caso brasileiro, as seguintes ferramentas: 
A) verificação do licenciamento ambiental, seja on-line, seja mediante solicitação de certidão - operações às quais se deve aplicar essa ferramenta: todas aquelas que envolvem atividades sujeitas a licenciamento, não importando o valor;

b) avaliação de impactos ambientais, seja usando questionários respondidos pelo empreendimento (preferencialmente específicos para o setor econômico em que ele atua), seja mediante análise documental - operações às quais se deve aplicar essa ferramenta: todas aquelas que envolvem atividades sujeitas a licenciamento; considerando-se que se trata de ferramenta muito mais trabalhosa que a primeira, é razoável considerar que ela seja utilizada tão somente para setores de maior risco ambiental, e que, para os setores de menor risco, seja utilizada apenas em operações de valores mais altos;

c) verificação da regularidade ambiental no que diz respeito à reserva legal e às áreas de preservação permanente da propriedade rural - operações às quais se deve aplicar essa ferramenta: todas aquelas que envolvem crédito rural, não importando o valor, sobretudo no bioma Amazônia (cf Resolução CMN 3545/2008); também é altamente recomendável que a mesma ferramenta seja utilizada para quaisquer outras atividades desenvolvidas na área rural;

d) verificação junto aos órgãos ambientais da eventual sobreposição com áreas ambientalmente protegidas (unidades de conservação) ou seu entorno (zona de amortecimento) - operações às quais se deve aplicar essa ferramenta: todas aquelas que envolvem crédito rural, não importando o valor; também é altamente recomendável que a mesma ferramenta seja utilizada para quaisquer outras atividades desenvolvidas na área rural (como mineração e obras de infraestrutura) e mesmo na área urbana, já que também existem unidades de conservação no perímetro urbano;

e) verificação junto à FUNAI de eventual sobreposição com áreas indigenas, ainda que em processo de demarcação - operações às quais se deve aplicar essa ferramenta: todas aquelas que envolvem crédito rural, não importando o valor; também é altamente recomendável que a mesma ferramenta seja utilizada para quaisquer outras atividades desenvolvidas na área rural e mesmo na área urbana, já que também existem (embora sejam raros) territórios indígenas no perímetro urbano;

f) verificação junto ao INCRA de eventual sobreposição com territórios de comunidades quilombolas, ainda que em processo de demarcação 
- operações às quais se deve aplicar essa ferramenta: todas aquelas que envolvem crédito rural, não importando o valor; também é altamente recomendável que a mesma ferramenta seja utilizada para quaisquer outras atividades desenvolvidas na área rural e mesmo na área urbana, já que também existem (embora sejam mais raros) territórios quilombolas no perímetro urbano;

g) monitoramento remoto (utilizando Google Earth ou ferramentas similares), com a finalidade de verificar os itens "d", "e" e "f" acima - a vantagem de utilizar tal ferramenta é a provável maior agilidade na obtenção das informações, dada a limitação dos bancos de dados disponíveis online e possível lentidão no fornecimento de certidões pelos órgãos públicos mencionados;

h) verificação da regularidade da outorga de direito de uso de recursos hídricos, quando for o caso - operações às quais se deve aplicar essa ferramenta: todas aquelas que envolvem crédito rural, assim como outras atividades econômicas que exijam a exploração de recursos hídricos, como mineração e algumas indústrias de base e de transformação, não importando o valor envolvido;

i) verificação do enquadramento da atividade financiada no Zoneamento Ecológico-Econômico (ZEE) - operações às quais se deve aplicar essa ferramenta: todas, sempre que houver ZEE implantado na região;

j) verificação da existência de restrições ao uso da propriedade (em razão de proteção ao patrimônio cultural, por exemplo) e sua compatibilidade com o projeto proposto -

operações às quais se deve aplicar essa ferramenta: todas aquelas que envolvem empreendimentos imobiliários, não importando o valor;

k) verificação on-line ou solicitação de certidões dos órgãos públicos ambientais (federal e estadual) quanto à existência e objeto de processos administrativos envolvendo o empreendimento ou quanto à existência de embargos sobre a área onde se desenvolverá a atividade financiada - operações às quais se deve aplicar essa ferramenta: todas aquelas que envolvem atividades sujeitas a licenciamento, não importando o valor; 1) verificação on-line ou solicitação de certidão do Ministério do Trabalho quanto à existência, objeto e andamento de processos administrativos em matéria de saúde e segurança do trabalho - operações às quais se deve aplicar essa ferramenta: todas, com ênfase nos setores em que a incidência de trabalho em condições inadequadas é mais intensa, quais sejam: agropecuária, construção civil e indústria têxtil; 
m) solicitação de certidões da Justiça do Trabalho, quanto ao número e objeto das ações envolvendo o empreendimento - operações às quais se deve aplicar essa ferramenta: todas, devendo haver comparação com o volume de mão de obra empregada pela empresa;

n) verificação das ações judiciais envolvendo o empreendimento na Justiça Estadual e Federal, com foco em ações referentes a matéria ambiental ou envolvendo outros direitos coletivos - operações às quais se deve aplicar essa ferramenta: todas aquelas que envolvem atividades sujeitas a licenciamento, não importando o valor;

o) verificação junto ao Ministério Público Federal de inquéritos civis, ações civis públicas e termos de ajuste de conduta envolvendo o empreendimento - operações às quais se deve aplicar essa ferramenta: todas aquelas que envolvem atividades sujeitas a licenciamento, não importando o valor;

p) verificação junto ao Ministério Público Estadual de inquéritos civis, ações civis públicas e termos de ajuste de conduta (TACs) envolvendo o empreendimento - operações às quais se deve aplicar essa ferramenta: todas aquelas que envolvem atividades sujeitas a licenciamento, não importando o valor;

q) verificação junto ao Ministério Público do Trabalho de informações sobre Termos de Ajuste de Conduta (TACs) firmados em inquéritos civis ou ações civis públicas (ACPs), além de informações sobre inquéritos civis - operações às quais se deve aplicar essa ferramenta: todas aquelas que envolvem atividades sujeitas a licenciamento, não importando o valor;

r) inspeções mediante comparecimento de especialista ao local das atividades financiadas, compatível com o grau de complexidade das operações - operações às quais se deve aplicar essa ferramenta: apenas as que envolvam grandes empreendimentos, sobretudo quando também forem altos os valores envolvidos;

s) pesquisa de mídia envolvendo o empreendimento elou o projeto financiado, bem como diálogo com instituições do terceiro setor com atuação relevante e reconhecida na área socioambiental - operações às quais se deve aplicar essa ferramenta: todas aquelas que envolvem atividades sujeitas a licenciamento; considerando-se tratar-se de ferramenta que, embora apresente baixo custo, é razoavelmente trabalhosa, dada a necessidade de avaliação das informações obtidas, é razoável considerar que ela seja utilizada tão somente para setores de maior risco ambiental, e que, para os setores de menor risco, seja considerado o valor envolvido na operação; 
t) contratação de auditoria socioambiental independente, preferencialmente com exame prévio da capacidade técnica e imparcialidade da empresa contratada - operações às quais se deve aplicar essa ferramenta: apenas as que envolvam grandes empreendimentos, sobretudo quando também forem altos os valores envolvidos;

u) avaliação ambiental de garantias imobiliárias - operações às quais se deve aplicar essa ferramenta: todas em que houver apresentação de imóveis em garantia;

v) solicitação de plano de ação para mitigar riscos socioambientais, incluindo, se for o caso, a resolução de conflitos com a comunidade do entorno - operações às quais se deve aplicar essa ferramenta: em regra, apenas as que envolvam grandes empreendimentos, sobretudo quando também forem altos os valores envolvidos;

w) existência de certificação(ões) por entidade(s) reconhecida(s) quanto à adequação dos sistemas de gestão ambiental e de gestão de saúde e segurança do trabalho - operações às quais se deve aplicar essa ferramenta: apenas as que envolvam grandes empreendimentos, sobretudo quando também forem altos os valores envolvidos;

$\mathrm{x})$ verificação das informações constantes dos relatórios de sustentabilidadel responsabilidade social corporativa, caso o empreendimento possua, inclusive atribuindo pontos positivos à simples existência de tais relatórios - operações às quais se deve aplicar essa ferramenta: apenas as que envolvam grandes empreendimentos, sobretudo quando também forem altos os valores envolvidos;

y) verificação da inclusão (ou não) em índices de sustentabilidade de Bolsas de Valores ${ }^{13}$ - operações às quais se deve aplicar essa ferramenta: apenas as que envolvam grandes empreendimentos, com ações negociadas no mercado de capitais, sobretudo quando também forem altos os valores envolvidos.

\footnotetext{
13 A BM\&F BOVESPA no Brasil possui, desde 2005, o chamado Índice de Sustentabilidade Empresarial (ISE), no qual são incluídas as empresas que emitem títulos nela negociados com melhor desempenho em governança e socioambientalidade. Ela foi a quarta Bolsa de Valores no mundo a adotar tal iniciativa, sendo um dos mais consagradas (inclusive com empresas brasileiras que já compuseram o índice) o Dow Jones Sustainability Index (DJSI), da Bolsa de Nova Iorque. Para saber mais sobre o ISE, vide: <www.isebmf.com.br>.
} 


\subsection{Relevância da autorregulação e das melhores práticas no mercado}

Outro ponto que não poderájamais ser ignorado, em circunstâncias concretas envolvendo a análise de eventual responsabilidade de instituições financeiras por danos sociais ou ambientais causados por empreendimentos financiados, é a assunção de compromissos voluntários (ou autorregulação) por parte da instituição. A assunção de tais compromissos, em geral, é acompanhada de ampla divulgação, numa estratégia de marketing positivo que está apta a gerar evidentes benefícios para a reputação da instituição financeira. Trata-se de estratégia legítima, desde que empregada com a devida seriedade e coerência, ou seja, acompanhada da devida implementação dos compromissos assumidos.

Como se sabe, não somente a lei (enquanto norma geral) é fonte de obrigações; estas também podem ser assumidas em função de um ato de vontade, como a celebração de um contrato ou a adesão a um compromisso voluntário. $\mathrm{O}$ fato de se originarem de um ato de vontade não torna as obrigações menos cogentes, gerando um direito legítimo ao seu cumprimento por parte dos interessados - no caso, toda a coletividade.

Portanto, se uma instituição financeira é signatária, por exemplo, dos Princípios do Equador $^{14}$ e não aplica suas regras a uma operação de Project Finance, está presente o elemento culpa para que ela seja considerada responsável por eventuais danos sociais ou ambientais. $\mathrm{O}$ mesmo vale para quaisquer outras iniciativas autorregulatórias, tais como a declaração de princípios dos Bancos que integram a UNEP-FI (United Nations Environmental Program - Finance Initiative ${ }^{15}$ ), o Pacto Global $\left(\right.$ Global Compact ${ }^{16}$ ), a Declaração do Capital Natural (firmada durante a Rio +20, em 2012), os Princípios dos Investimentos Responsáveis (PRI - Principles for Responsible Investments ${ }^{17}$ ), os Green Bonds Principles ${ }^{18}$, o Carbon Disclosure Project ${ }^{19}$, para mencionar apenas as iniciativas mais relevantes atualmente existentes no âmbito do mercado financeiro ${ }^{20}$, ou

14 Para saber mais, ver: <equator-principles.com>

15 Para saber mais, ver: $<$ www.unepfi.org $>$.

16 Para saber mais, ver: $<w w w . u n g l o b a l c o m p a c t . o r g>$.

17 Para saber mais, ver: <www.unpri.org $>$.

18 Para saber mais, ver: $<w w w . i c m a g r o u p . o r g>$.

19 Para saber mais, ver: <www.unpri.net $>$.

20 Para uma descrição de cada uma destas iniciativas, vide capítulo II do seguinte trabalho: SOUZA, Luciane Moessa de. Sustentabilidade socioambiental no sistema financeiro: diagnóstico e propostas. Relatório de Pesquisa de Pós-Doutorado. Universidade de São Paulo (USP), abril de 2016. 
outras que venham a ser criadas.

Por fim, a relevância das melhores práticas diz respeito à necessidade de se estabelecer parâmetros adequados para interpretação de normas regulatórias com redação vazada em termos genéricos, permitindo verificar o que seria um nível mínimo, um nível médio e um nível ideal de diligência a ser adotado em cada operação de crédito ou investimento.

\subsection{Relevância das informações publicamente divulgadas pela própria instituição financeira, dos manuais internos e da adequação da estrutura de governança}

Outro elemento de fundamental importância, a ser ponderado de acordo com o porte da instituição financeira, são as informações que ela própria disponibiliza em seu sítio eletrônico (ou outras fontes) acerca de seus critérios e procedimentos para gerenciamento de riscos socioambientais, os quais também devem ser tidos como vinculantes.

Além disso, podem e devem ser examinados os manuais e outros documentos internos que tratam do tema, bem como a existência (ou não) de estrutura de governança adequada à sua efetividade - incluindo-se ações de capacitação das pessoas responsáveis, monitoramento das operações de crédito e investimentos (quando for o caso) e auditoria quanto à observância das normas divulgadas interna e externamente - tudo com periodicidade e grau de profundidade adequados ao nível de complexidade das operações.

\subsection{Relevância da natureza da operação, das cláusulas contratuais e dos procedimentos adotados no caso concreto}

Por último, mas talvez mais importante de tudo, devem-se examinar a profundidade e qualidade da análise de riscos socioambientais que foi realizada no caso concreto (à luz do setor econômico e da região de que se trate); se foram buscadas e examinadas todas as informações publicamente disponíveis, bem como outras a serem obtidas diretamente com o empreendedor; se foram (ou não) exigidas dele algumas adequações;se as conclusões da análise/avaliação de risco socioambiental realizada foram adotadas; se foram inseridos nos contratos pertinentes deveres de conformidade com as obrigações ambientais e sociais; se houve monitoramento dessa regularidade ao menos durante a fase de desembolso 
de recursos ${ }^{21}$; se houve suspensão do desembolso de recursos em caso de ser detectada alguma irregularidade, enfim, se a instituição financeira efetivamente realizou tudo o que estava ao seu alcance para evitar o dano - não se podendo, no limite, exigir dela que assumisse a gestão do empreendimento, naturalmente.

É evidente que eventuais detalhamentos das normas regulatórias já existentes têm uma grande contribuição a fazer nesse aspecto. Como anotam Consuelo Yoshida e Renata Piazzon, no caso brasileiro, a atual Resolução CMN nº. 4.327, de 2014,

[...] se limita a estabelecer diretrizes e critérios gerais bastante abrangentes, não detalhando o que exatamente os bancos devem solicitar aos seus clientes para que seja resguardada a regularidade ambiental de determinado empreendimento - diligência ambiental mínima. [...]

Não obstante, o setor financeiro possui uma expectativa legítima de que a Resolução $\mathrm{n}^{\circ} .4 .327$ seja interpretada e aplicada de forma que permita a ação dos bancos dentro de uma esfera de maior segurança jurídica. ${ }^{22}$

\section{SOLIDARIEDADE E DOSAGEM DO GRAU DE CULPA}

Em matéria de reparação de danos ambientais, por uma série de fatores muito bem resumida por Nusdeo (2017, p. 30), como, de um lado, a indivisibilidade dos danos ambientais, e, de outro, a possibilidade de haverem múltiplos autores e eventual impossibilidade de mensurar com exatidão o grau de contribuição de cada $u^{23}{ }^{23}$, vigora, em regra, o regime de responsabilidade solidária entre os vários poluidores quanto ao dever de

21 No mesmo sentido, Ana Luci Grizzi e outras afirmam: "O financiador deve monitorar a aplicação dos recursos por ele disponibilizados ao longo do financiamento, cumprindo, dessa forma, seu dever constitucional de preservar e defender o meio ambiente ecologicamente equilibrado, essencial à sadia qualidade de vida." (2003, p. 37) Registre-se que o regulador bancário chinês traz essa obrigação de monitoramento ao longo de toda a operação, de forma expressa, pois, caso surjam riscos socioambientais elevados, poderá ser o caso de se constituir provisões por esse motivo. Como consta no relatório de Pós-Doutorado de Luciane Moessa, já referido, na China, “em 2007, o SEPA [State Environmental Protection Administration), o Banco Central e a CBRC [China Banking Regulatory Commission] expediram Recomendações sobre a 'Implementação de Políticas de Proteção Ambiental e Normas para evitar Riscos de Crédito', requerendo que tanto os órgãos ambientais quanto as instituições financeiras compreendessem políticas de crédito como ferramentas para proteção ambiental, e fortalecessem o monitoramento ambiental na gestão do crédito para construção de projetos e financiamento a empreendimentos." (2016, p. 93)

22 Responsabilidade socioambiental dos bancos. Valor Econômico. São Paulo, 27 de maio de 2014.

23 É o que ocorre no caso de diversas fábricas vizinhas que despejem poluentes num mesmo rio ou poluam o mesmo ar ou, ainda, na hipótese de existirem danos ambientais anteriores, aos quais se soma um dano mais recente. 
reparar o dano ambiental.

Quanto ao regime subjetivo de responsabilidade civil por danos ambientais, Dal Maso relata que, na Itália, as instituições respondem no limite de sua responsabilidade individual, e não de forma solidária (2001, p. 37), como ocorre no Brasil.

No caso brasileiro, ainda que a regra seja a solidariedade, quando se vê envolvido um poluidor indireto, novamente é o caso de fazer uma distinção de regime, devendo, a meu ver, ser reconhecido que a esse cabe responsabilidade subsidiária - o que, de forma alguma impede, naturalmente, a propositura de ação judicial simultânea contra ambos (como ocorre, por exemplo, em relação ao tomador dos serviços e a empresa terceirizada que realize intermediação de mão de obra, na esfera trabalhista). Assim, o patrimônio do poluidor indireto não será atingido em primeiro lugar, e sim, apenas em caso de insuficiência patrimonial do poluidor direto. Fica garantida a reparação do dano, mas também uma atribuição das suas consequências financeiras proporcional ao grau de responsabilidade na sua causação.

Merece referência a posição de Consuelo Yoshida, que defende a adoção de um sistema que ela denomina de "responsabilidade compartilhada", apropriado à cadeia real de fatos no caso concreto, em substituição ao de responsabilidade solidária que tem sido adotado, e que acaba penalizando, muitas vezes, em primeiro lugar, o financiador. Sustenta ela:

Portanto, dentro das lógicas da sustentabilidade e da observância das normas ambientais, a solidariedade passiva, que possibilita a responsabilização de um só coobrigado (geralmente o de maior capacidade econômica) pela totalidade das obrigações em caso de descumprimento por qualquer dos coobrigados, passa a ser de aplicação subsidiária em relação à responsabilidade compartilhada que alcança todos os atores (estatais, econômicos e sociais) na gestão público-privada, proativa e integrada das questões socioambientais. Não sendo exitosos os resultados esperados com a utilização da responsabilidade compartilhada, cabe a responsabilidade solidária, de aplicação subsidiária, neste sentido. (2012, p. 122)

Estou de pleno acordo no que concerne à desnecessidade de aplicação automática do regime de solidariedade, devendo adotar-se, isto sim, o de responsabilidade subsidiária. 


\section{LIMITAÇÃO DA RESPONSABILIDADE NO TEMPO}

Rômulo Sampaio, em sua obra dedicada ao tema (2013, p. 199-201), se contrapõe mais uma vez ao pensamento de Alexandre Raslan, quando este defende uma responsabilidade ilimitada no tempo das instituições financeiras pelos danos ambientais causados pelos empreendimentos financiados, em razão da reconhecida imprescritibilidade do dano ambiental (2012, p. 251). O regime de imprescritibilidade, vale lembrar, existe justamente porque os danos ambientais podem demorar longo tempo para eclodir.

Para Grizzi e outras (2003, p. 56-57) e Sampaio, todavia, deve haver um limite temporal, que as primeiras propõem seja o termo final de vigência do contrato de financiamento, desde que o financiador tenha dado pleno cumprimento às disposições legais aplicáveis ao crédito, como exigir a comprovação do licenciamento ambiental e regularidade das atividades - deveres que, para elas (assim como para o Prof. Paulo Affonso Leme Machado), se estendem também aos bancos privados. Já Sampaio propõe que essa limitação temporal seja estabelecida a partir da liberação da última parcela do crédito (2013, p. 196), mesmo antes da quitação, desde que a análise de regularidade ambiental tenha sido feita antes da aprovação do crédito e da liberação de cada parcela.

Nesse aspecto, entendo que assiste inteira razão a Raslan, pois não se pode atribuir ao mero acaso a consolidação de uma situação jurídica cujos efeitos ambientais são prolongados, cabendo, sim, reconhecer a imprescritibilidade do direito à reparação do dano ambiental também em face do seu causador indireto - o que é mais um incentivo para que as diligências socioambientais no momento da aprovação da operação sejam as mais amplas possíveis, concretizando, assim, o princípio da prevenção em sua máxima dimensão.

\section{O PROBLEMA DAS GARANTIAS IMOBILIÁRIAS CONTAMI- NADAS}

Em todo o mundo, a primeira aparição da relevância da questão ambiental se dá quando os bancos se deparam com garantias imobiliárias, cujo valor é muito inferior ao estimado, em razão da contaminação do solo, podendo chegar a ser negativo, conforme os custos envolvidos na descontaminação, como relata Davide dal Maso (2001, p. 28). Também o 
relatório elaborado pela ISIS em 2002 após pesquisa com grandes bancos europeus afirma que

[...] o primeiro evento ou 'gatilho' a desencadear a consciência ambiental dos bancos foi a experiência de se tornar possuidor de imóveis contaminados que haviam sido recebidos em garantia, cujos custos de descontaminação poderiam exceder o valor do empréstimo. O segundo foi a ocorrência de incidentes com poluição gravíssima. (2002, p. 9)

Todos os autores que examinaram esse tema fazem referência, como já dito, ao exemplo dos EUA, que se inicia com a previsão legal, em 1980, de que os proprietários atuais seriam titulares do dever de indenizar o governo do país pela descontaminação das áreas, ainda que não tivessem sido responsáveis diretos pela contaminação no passado. A legislação estadunidense (Comprehensive Environmental Response, Compensation and Liability Act, expedido em 1980) criou um "superfundo" de natureza pública com a finalidade de proceder à descontaminação de áreas poluídas, porém, com direito de regresso em face dos proprietários. Em 1986 (Superfund Amendment and Reauthorization Act), a norma foi alterada para prever um regime de responsabilidade objetiva por danos causados pelos proprietários, isentando, contudo, os credores que se tornassem proprietários por conta da execução de garantias. Apesar da redação legal, após executar suas garantias imobiliárias, alguns bancos acabaram sendo condenados a indenizar a agência ambiental dos EUA (Environmental Protection Agency - EPA) pelos custos da descontaminação, por ter sido considerado que eles tinham ingerência direta na gestão da empresa poluidora.

Para tentar resolver o problema, a agência disciplinou o assunto por norma regulamentar, em 1992, estabelecendo limites para a caracterização da responsabilidade dos bancos, mas o Judiciário entendeu, em 1994, que o tema somente poderia ser tratado por lei, suspendendo a eficácia da norma. Em 1996, foi promulgada lei (Asset Conservation, Lender Liability and Deposit Insurance Protection Act) estabelecendo critérios semelhantes àqueles previstos na norma administrativa invalidada, quais sejam: a) os bancos não seriam responsáveis, caso permanecessem com o imóvel apenas pelo tempo necessário para transferi-lo a terceiros, com o fito de receber o seu crédito; b) os bancos seriam responsáveis, caso se demonstrasse que houve participação efetiva na gestão da empresa poluidora. Enquanto isso 
não foi definido pela lei federal de 1996, os efeitos no mercado de crédito no início dos anos 1990 se fizeram sentir: Dal Maso noticia que, segundo uma determinada entidade empresarial do setor de petróleo, cerca de um terço das demandas de crédito tenha sido negado à época, a maior parte em razão de temores pelos riscos ambientais. De outra parte, $15 \%$ dos bancos se queixavam de terem se deparado com garantias imobiliárias que não valia a pena executar em razão de contaminação. Da mesma forma, ele relata que na Europa casos similares (custos elevadíssimos de descontaminação que tornavam prejudicada a garantia) foram comuns na década de 1990 (2001, p. 35). Segundo ele, a posição mais exposta aos riscos de responsabilização civil por danos ambientais é justamente a do proprietário de imóvel, sendo que, "em alguns países, como a Finlândia, Holanda, Reino Unido, Suécia, Suíça e Espanha, a responsabilidade também pode ser atribuída à empresa controladora que exerça efetivo controle da atividade empresarial." (2001, p. 39 , tradução minha).

Jeucken relata os efeitos da decisão judicial mais famosa sobre o tema (The USA X Fleet Factors Corporation), por meio da qual o banco foi condenado a indenizar os custos da descontaminação, sob o fundamento de que, por estar encarregado da administração financeira da empresa poluidora, tinha a "capacidade de influenciar" as decisões que resultaram na contaminação (2004, p. 168). Os efeitos da decisão se fizeram sentir claramente no setor bancário: segundo um estudo da Associação de Bancos Americanos (American Bankers Association), 88\% deles modificaram suas políticas de crédito a partir de então para evitar serem responsabilizados por danos ambientais; $63 \%$ rejeitaram operações de crédito com esse receio; $17 \%$ preferiram deixar de executar garantias imobiliárias por temor de contaminação do solo; $14 \%$ tiveram que arcar com os custos de imóveis que foram recebidos em garantia; $46 \%$ deixaram de conceder crédito a alguns setores ambientalmente sensíveis, como indústria química e agricultura (em especial bancos menores). Além disso, os bancos começaram a estabelecer taxas de juros diferenciadas e reduzir prazos de carência para operações com setores com riscos ambientais mais elevados, e também começaram a criar procedimentos para auditorias ambientais (2004, p. 168).

\section{RESPONSABILIDADE NO CASO DE ATIVIDADES DE INVESTIMENTOS}

Emrelação às atividades desenvolvidas por instituições financeiras 
no mercado de capitais, por envolverem, em regra, empreendimentos de grande porte e muitas vezes setores econômicos bastante sensíveis do ponto de vista socioambiental, o tema também se apresenta como bastante relevante.

Rômulo Sampaio, ao examinar o tema da responsabilidade da instituição financeira com relação ao mercado de investimentos, o fez com relação a uma única atividade, típica de banco de investimentos: a atuação como coordenadora líder ou distribuidora de títulos no mercado de capitais, que envolve uma série de atribuições administrativas junto à CVM e à Bolsa de Valores, mas cuja finalidade principal é emprestar sua credibilidade à empresa emissora dos títulos, aproximando-a de seus clientes que possam ter interesse na aquisição. Seguem as principais ilações dele nesse aspecto:

[...] ao estruturar uma operação de mercado, deve a instituição financeira estar atenta ao risco ambiental da atividade estruturada. Deve incorporar à análise de risco da operação o risco operacional da empresa que pretende abrir o capital para a exposição da corporação ao risco ambiental. Deve também utilizar a força da sua reputação para o sucesso da operação de abertura de capital para forçar a empresa a internalizar deveres de cuidado com a sua atuação naquilo que coloca em risco o meio ambiente. (2013, p. 191)

Assim, para esse autor, o que se deve exigir da instituição financeira, com relação a esse tipo de atuação é que ela realize uma análise do risco ambiental da empresa que pretende captar novos investimentos no mercado de capitais: "deve-se buscar o nível de informação disponível no momento da operação e, acima de tudo, os esforços empregados pela instituição financeira para buscar a informação sobre o risco operacional da empresa objeto da operação de abertura de capital." (2013, p. 192).

O raciocínio é adequado, na linha do que propus em termos de responsabilidade subjetiva: deve-se exigir da instituição financeira o grau de diligência compatível com os riscos do setor econômico, o porte da empresa e mesmo o valor envolvido na operação.

Entendo que todos os parâmetros referidos no item 2 devem ser considerados, inclusive porque várias instituições financeiras já divulgam seus parâmetros e procedimentos para avaliação dos riscos socioambientais nos investimentos - o que é uma boa prática, demonstrando seriedade e transparência, mas que também gera responsabilidade em face de todos os 
compromissos assumidos publicamente ou mesmo contratualmente com seus clientes, como se dá nas atividades de gestão de ativos financeiros. Os mesmos critérios podem e devem ser estendidos às demais atividades similares no mercado de investimentos.

Rômulo Sampaio retomou o tema em estudo realizado em coautoria com outros pesquisadores e publicado como Working Paper da UNEP Inquiry em 2016. Ali, eles propõem critérios que buscam diferenciar o grau de responsabilidade do investidor tanto com base em níveis de capacitação técnica e capacidade econômica quanto de acordo com a modalidade de investimento. Sob esse último aspecto, afirmam eles: "[p]or exemplo, o investimento em quotas sociais (private equity) permite um acesso a um nivel muito maior de informações sobre a companhia investida e seus projetos do que no caso de um fundo de investimentos." (2017, p. 22, tradução minha). De fato, fundos de investimentos costumam contemplar diversas empresas e as posições do sócio-quotista de uma sociedade empresarial de responsabilidade limitada e do acionista de uma sociedade anônima, em regra, são bastante diferenciadas em termos de controle e acesso a informações. Já quanto à situação do investidor, eles propõem que ela seja diferenciada em três categorias: a) seriam considerados altamente qualificados os investidores institucionais, que têm um grau maior de influência na gestão dos negócios investidos, ao fazerem investimentos de grande valor; b) seriam considerados apenas qualificados os investidores institucionais, ao fazerem investimentos de menor valor ou com menor grau de ingerência no negócio; c) por último, a terceira situação seria a dos investidores que recebem pouca ou nenhuma informação sobre os projetos/empreendimentos receptores de investimentos, e que se utilizam de gestores de investimentos (2017, p. 22-23).

A ideia de diferenciar consoante o grau de controle e nível de acesso às informações é adequada, mas essa classificação não é operacional, pois investidores institucionais, por exemplo, costumam também contratar gestores de investimentos. Muitas situações ensejariam dúvidas, como a dos "family offices", escritórios especializados na gestão dos ativos financeiros de famílias abastadas. Ademais, mesmo no caso de investidores institucionais, é preciso reconhecer que, muitas vezes, o investimento pode ter valor elevado, mas o percentual é muito pequeno para ter influência tão relevante na gestão da companhia investida quanto se poderia esperar. Situação diferente é a do investidor que tem assento em algum Conselho da empresa investida. Se ele detiver, então, a maior parte das ações, como 
entendem com razão Sampaio e outros (2016, p. 23), a responsabilidade por danos socioambientais causados pelo empreendimento é integral.

Sampaio e outros sugerem que, em caso de uso de gestores de fundos de investimentos (ou outras modalidades), as duas últimas categorias de investidores não seriam alcançadas, mas tão somente os gestores. A meu ver, cabe analisar também o que estabelecia o contrato de gestão de investimentos, se ele exigia que fatores socioambientais fossem identificados e levados em conta sob o aspecto dos riscos envolvidos e como um critério para investir, desinvestir ou engajar-se com as empresas receptoras de investimentos, e o quanto ele era detalhado em termos de diligências a serem realizadas. Se houve descumprimento contratual, não é necessário ingressar na seara da responsabilidade objetiva. É importante lembrar que, para investidores no varejo, não há possibilidade alguma de negociação de cláusulas contratuais, de modo que o grau mínimo de diligência a se exigir dos gestores independe de previsão contratual.

Mesmo para os investidores institucionais, e no que se refere a investimentos de maior valor ou proporção, entendo que não é necessário ingressar no campo da responsabilidade objetiva, bastando, como dito, adotar-se os mesmos critérios propostos para o crédito. Vale lembrar que, diferente das instituições financeiras que concedem crédito, os investidores em renda variável já sofrerão os impactos financeiros de qualquer forma, pois a empresa terá que indenizar os danos ambientais independentemente de culpa, e isso afetará seus resultados. Tendo em conta, entretanto, o regime de limitação da responsabilidade que vigora tanto para sociedades limitadas quanto para sociedades anônimas (salvo as hipóteses de desconsideração da personalidade jurídica), o maior risco para investidores reside na perda de rentabilidade, perda de valor dos ativos ou perda dos próprios ativos, caso o patrimônio da empresa investida seja igual ou ao valor da reparação integral dos danos.

A grande questão que se coloca, entretanto, diz respeito a duas outras esferas de responsabilização:

a) relação entre entidades de previdência complementar e participantes dos planos e o dever fiduciário de exercer com diligência a gestão dos ativos financeiros, levando em conta, portanto, também os riscos de natureza socioambiental (dever já explicitado pela regulação no caso das entidades fechadas, como visto);

b) relação contratual entre investidores institucionais (entidades de previdência e seguradoras) ou mesmo demais investidores e as gestoras de ativos financeiros, que 
também exige que a gestão contratada leve em conta quaisquer riscos financeiramente relevantes.

É evidente que, em qualquer das hipóteses acima (perda da rentabilidade esperada, perda de valor dos ativos ou perda integral dos próprios ativos), caso essa perda financeira esteja relacionada a fatores socioambientais, os participantes de planos de previdência poderão demandar as entidades à qual se vincularam e os investidores poderão demandar as gestoras de ativos que contrataram sempre que considerarem que não houve adequado grau de diligência no levantamento e análise de informações socioambientais sobre a(s) empresa(s) investida(s), imóvel(is) ou outra classe de ativos na qual tenha ocorrido a perda. Nesse caso, há de se analisar justamente se os deveres de diligência foram adequadamente desempenhados, à luz dos parâmetros propostos no item 2 .

\section{A JURISPRUDÊNCIA BRASILEIRA}

Não obstante o importante julgado do Superior Tribunal de Justiça (STJ), cujo relator é o Ministro que é o maior especialista em Direito Ambiental (como também o é em Direito do Consumidor) naquele tribunal, Antônio Herman Benjamin, referido no início deste capítulo, adote o entendimento da responsabilidade objetiva (em processo no qual, porém, nenhuma instituição financeira era parte), as decisões de tribunais de segunda instância acerca do tema (sujeitas a recurso ao STJ, naturalmente) destoam daquele entendimento. O Tribunal Regional Federal da $1^{\mathrm{a}}$. Região tem alguns julgados relevantes, porém, proferidos há quase duas décadas:

"PROCESSUAL CIVIL. OBRA PÚBLICA. DANO AMBIENTAL. CEF FINANCIAMENTO. ILEGITIMIDADE DE PARTE.

I - Na qualidade de mera financiadora de obra pública, não sendo responsável pela sua construção e tampouco pelo projeto, a Caixa Econômica Federal não pode ser responsabilizada por eventuais danos ambientais decorrentes da sua realização.

II - Ilegitimidade de parte que se reconhece.

III - Competência da Justiça Federal afastada.

IV - Agravo de Instrumento a que se nega provimento."

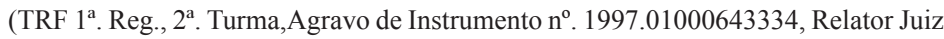
convocado Antônio Savio O. Chaves, Julg. 11. 12.2000) 
“[...] não obstante a legislação brasileira dê amparo à responsabilidade civil objetiva e solidária das instituições financeiras em decorrência da concessão do crédito, a atividade causadora de danos ambientais, a exclusão ou atenuação do nexo de causalidade devem ser objeto de discussão em face de cada caso concreto, considerando-se, entre outras hipóteses, o cumprimento do dever de diligência imposto às entidades de crédito oficiais pelo art. 12 da Lei n ${ }^{\circ}$. 6.938/81, que aperfeiçoa a disciplina embrionária do art. 12 da Lei $n^{\circ}$. 6.803/80.

Embora ambas as disposições legais se refiram à atuação preventiva das instituições de crédito oficiais e às operações de financiamento e incentivos governamentais, é salutar, pelas razões apontadas, interpretá-las ampliativamente para alcançarem também as instituições privadas [...]

Quanto ao BNDES, o simples fato de ser ele a instituição financeira incumbida de financiar a atividade mineradora da CMM, em princípio, por si só, não o legitima para figurar no polo passivo da demanda.

Todavia, se vier a ficar comprovado, no curso da ação ordinária, que a referida empresa pública, mesmo ciente da ocorrência dos danos ambientais que se mostram sérios e graves e que refletem significativa degradação do meio ambiente, ou ciente do início da ocorrência deles, houver liberado parcelas intermediárias ou finais dos recursos para o projeto de exploração minerária da dita empresa, aí sim, caber-lhe-á responder solidariamente com as demais entidades-rés pelos danos ocasionados no imóvel de que se trata, por força da norma inscrita no art. 225 , caput, $\S 1^{\circ}$., e respectivos incisos, notadamente os incisos IV, V e VII, da Lei Maior.” (AG 2002.01.00.036329-1/MG, Relator Des. Fagundes de Deus, Julg. 15.12.2003 - destaquei)

\section{Veja-se também a seguinte ementa de decisão de um Tribunal de} Justiça estadual:

“AÇÃO CIVIL PÚBLICA - MINISTÉRIO PÚBLICO - PROCEDÊNCIA EM $1^{\circ}$. GRAU - FINANCIAMENTOS OU INCENTIVOS RURAIS - EXIGÊNCIA NO CUMPRIMENTO DA LEGISLAÇÃO AMBIENTAL - INEXISTÊNCIA DE

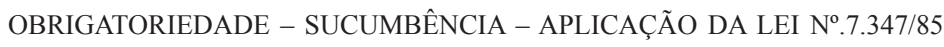
- RECURSO PROVIDO.

Inadmissível, especialmente quando não vem olvidando o Banco apelante nenhuma exigência legal protetiva do meio ambiente, responsabilizá-lo por uma possível ocorrência de agressão ambiental."

(TJ-MT, 2 ${ }^{\mathrm{a}}$. Câmara Cível - Recurso de Apelação Cível - classe II - 19 - n. 25.408 -

Capital; Relator Des. Benedito Pereira do Nascimento; Julgamento em 17.4.2001). 
Em relação a esse julgado, no qual o apelante era o Banco do Brasil, vale enfatizar que também foi proferido no longínquo ano de 2001, adotando uma interpretação literal do art. 12 da Lei 6.938/1981 como abrangente tão somente do financiamento a projetos e excluindo, portanto, as operações de crédito rural. Como visto no capítulo IV, desde 2008, a Resolução CMN 3.545 passou a vedar a concessão de crédito rural no bioma Amazônia, quando a propriedade esteja em desacordo com a legislação ambiental. No caso em tela, a propriedade não possuía reserva legal e o Banco do Brasil não fez essa exigência - daí a motivação da atuação judicial do Ministério Público.

Além disso, em julgado monocrático do próprio STJ, esse bem mais recente (de 2014), uma Ministra convocada já adotou entendimento diverso daquele do Ministro Herman Benjamin, sendo fundamental ressaltar, todavia, que, no caso em questão, o projeto financiado pela instituição financeira (um banco multilateral, o Banco Interamericano de Desenvolvimento) foi conduzido por um ente público, no caso o Estado de São Paulo, que também tinha a competência de realizar eventual licenciamento ambiental. Destaco os trechos essenciais da decisão:

“O cerne da questão veiculada na ação ordinária ajuizada na origem focava, especificamente, a reparação pelos danos ambientais ocasionados na efetivação do Projeto Várzeas do Tietê, atribuídos à Fazenda Pública do Estado de São Paulo e outros.

$[\ldots]$

Na espécie, a decisão agravada extinguiu o feito com relação ao Banco Interamericano de Desenvolvimento - BID, à base da seguinte fundamentação:

[...] 'Não se provou, nem se indicou por qualquer modo, que a ele coubesse exigir a realização de estudos acerca do impacto ambiental das obras projetadas com os recursos disponibilizados.[...]

A ausência ou o erro dos estudos acerca do impacto ambiental do projeto, que não se logrou demonstrar sejam imputáveis ao BID, é que poderão dar azo ao dano, caso venha a ser comprovado.'[...]

No presente caso, em uma primeira análise, não se vislumbra qualquer responsabilidade do BID pelos danos ambientais ocasionados na execução do Projeto Várzeas do Tietê, sendo parte ilegítima para ocupar o polo passivo da presente demanda."

(STF - Ag. 1433170 - Relatora Ministra Marga Tessler (juíza convocada do TRF 4ª Região) - DJe 11.12.2014) 
Esse quadro parece indicar queo reconhecimento da necessidade de caracterização de culpa e a construção de parâmetros seguros para tal fim se afigura um caminho mais seguro e sensato para a responsabilização (ou não) de instituições financeiras (aí entendidas num sentido amplo, abrangendo concedentes de crédito e investidores) em razão de danos ambientais causados por empreendimentos, obras ou projetos financiados.

\section{SIGILO BANCÁRIO E INFORMAÇÕES DE INTERESSE SOCIOAMBIENTAL}

A Lei Complementar $n^{\circ} .105$, de 10 de janeiro de 2001, dispõe sobre a abrangência do sigilo bancário, tanto para instituições financeiras quanto para os órgãos que as fiscalizam, e também dispõe sobre as hipóteses em que esse sigilo pode ser quebrado. Não cabe aqui analisar esse complexo diploma normativo, mas sim sua repercussão sobre o tema dessa pesquisa.

Já o Decreto federal nº.99.274, de 6 de junho de 1990, em seu art. $19, \S 3^{\circ}$, dispõe:

\footnotetext{
$\S 3^{\circ}$. Iniciadas as atividades de implantação e operação, antes da expedição das respectivas licenças, os dirigentes dos Órgãos Setoriais do Ibama deverão, sob pena de responsabilidade funcional, comunicar o fato às entidades financiadoras dessas atividades, sem prejuízo da imposição de penalidades, medidas administrativas de interdição, judiciais, de embargo, e outras providências cautelares.
}

Trata-se, sem dúvida, de um excelente instrumento de prevenção de ilícitos ambientais. Porém, tendo em conta que o IBAMA não tem acesso direto às informações sobre quais são as instituições financiadoras de atividades que dependem de licenciamento, pois quem detém informações sobre operações de crédito é o Banco Central do Brasil (e ademais, elas estão acobertadas por sigilo bancário), a operacionalização dessa norma se torna bastante dificultada.

Ana Luci Grizzi e outras lembram, citando Paulo Affonso Leme Machado, que a Ação Civil Pública também "pode ser utilizada para conseguir-se informação sobre a observância da legislação ambiental em financiamento, quando esta informação estiver coberta pelo sigilo bancário" (2003, p. 61). 
Ainda, Alexandre Raslan destaca que boa parte das operações de crédito é acompanhada do oferecimento de um bem imóvel em garantia - e que essa operação, para produzir efeitos perante terceiros, precisa ser registrada no registro imobiliário, conforme determinam os arts. 16 e 17 da Lei 6.015, de 31 de dezembro de 1973. Assim, salienta ele, "viabiliza-se alternativa legal para a obtenção de informações bancárias" (2012, p. 233), tornando desnecessário, nesse caso, que se requeira ao Poder Judiciário a decretação da quebra de sigilo bancário para se ter acesso à informação.

O caminho ideal seria a alteração legislativa para que o Ministério Público e os órgãos ambientais pudessem requisitar diretamente ao Banco Central informações sobre operações bancárias, desde que pudessem demonstrar o relevante interesse coletivo envolvido, e porque essa informação seria indispensável para o esclarecimento dos fatos.

Independentemente de alteração normativa, porém, entendo que as informações obtidas no curso de ações de fiscalização, com relação aos manuais e procedimentos internos adotados pelas instituições financeiras para o gerenciamento de riscos socioambientais, bem como as avaliações de risco socioambiental elaboradas em operações determinadas, e as sucessivas ações de monitoramento, por não envolverem qualquer questão que afete a intimidade ou a vida privada de terceiros, e sim questões de relevante interesse coletivo, não estão acobertadas pelo sigilo bancário.

Ademais, com relação aos manuais que preveem critérios e ferramentas para avaliação de risco socioambiental, é inclusive perfeitamente possível que norma regulatória venha a prever o dever de as instituições realizarem a divulgação, de maneira que seus clientes e demais partes interessadas possam conhecer o seu grau de diligência e a consistência (ou não) de suas políticas de responsabilidade socioambiental, demonstrando, inclusive, aos potenciais tomadores de crédito ou receptores de investimentos, que serão criteriosamente avaliados quanto a esses aspectos, quando forem contratar com a instituição financeira.

Por fim, é importante referir, também como fundamento para esse raciocínio jurídico, que um dos princípios essenciais em matéria ambiental, consagrado tanto na Declaração de Estocolmo de 1972 quanto na Declaração do Rio de 1992 (por ocasião das Conferências das Nações Unidas para o Meio Ambiente) é o princípio da cooperação. Nas lições de Paula Silveira Galbiatti, que se dedicou a examinar as repercussões do princípio da cooperação em matéria ambiental para o Brasil, citando Cristiane Derani (1997, p. 42): 
[...] o princípio da cooperação é uma expressão do princípio genérico do acordo ou Kompromissprinzip, que perpassa toda a ordem jurídica, inclusive a ambiental, informando uma atuação conjunta da sociedade e do Estado na escolha de prioridades e processo decisórios, ou seja, é base para ampliação da informação e participação nos processos de decisão da política ambiental. (2015, p. 1318 - destaquei).

Mais adiante, a autora faz referência às lições de Guido Soares acerca do tema:

SOARES (2003a, p. 62-63) explica que a Declaração do Rio, de forma direta, reafirma em seu Preâmbulo os valores já proclamados na Declaração de Estocolmo, e busca avançar a partir dela. Nota-se na Declaração do Rio o objetivo primordial de cooperação para preservação e conservação do meio ambiente, para o desenvolvimento sustentável e para a promoção de um sistema de comunicação científica e de intercâmbio de informações. Somente com compartilhamento de informações e seu acesso pela sociedade é que os processos de decisão ambientais terão legitimidade e permitirão um diálogo entre os diversos setores, buscando a melhor solução. (2015, p. 1322 - destaquei)

Percebe-se, assim, que uma das repercussões do princípio da cooperação é justamente a ideia de compartilhamento de informações de natureza ambiental (inclusive entre países, mais ainda no âmbito interno de um país), uma vez que o assunto é, por interesse, de interesse coletivo.

\section{REFLEXÕES FINAIS ACERCA DAS RELAÇÕES ENTRE REPARAÇÃO E PREVENÇÃO DE DANOS SOCIOAMBIENTAIS}

Para arrematar esse capítulo, é importante estabelecer a correlação entre o sistema de responsabilização por danos socioambientais e a efetividade de um sistema de prevenção de tais danos.

Um tema que permeia muitas das discussões acerca do papel das instituições financeiras nesta seara é uma certa confusão entre papéis de reguladores ambientais (encarregados não apenas do licenciamento ambiental, como também da fiscalização de atividades potencialmente envolvidas em ilícitos ambientais - sob o aspecto das infrações administrativas, mas com reflexos nas esferas civil e penal) e de instituições 
financeiras. Penso que um exemplo muito básico seja capaz de bem elucidar a questão. Seria inviável, à luz de critérios jurídicos ou econômicos, exigir de instituições financeiras que examinassem cautelosamente a adequação ou acerto de cada licença ambiental concedida a seus clientes. Aline Pacheco Pelucio lembra muito bem que "alocar um custo no ator capaz de lidar com esse custo da forma mais eficiente (the best cost avoider reasoning) é a premissa microeconômica básica da análise econômica do Direito." (2017, p. 165). Pelo mesmo raciocínio, pode ser inviável esperar que a instituição financeira ou o investidor seja capaz de analisar se a fiscalização está sendo exercida com a frequência necessária ou se o órgão ambiental possui estrutura técnica e quadro de pessoal adequado a exercer o seu poder de polícia ambiental. A instituição financeira ou investidor até pode buscar se informar a respeito, tendo em vista que os riscos ambientais podem se refletir no desempenho econômico-financeiro de seu cliente ou empresa investida, mas exigir que a análise vá até esse ponto parece exceder os limites da razoabilidade.

Não parece, contudo, exceder esses limites entender que cabe a todas as instituições financeiras e investidores, públicos e privados, verificar se a atividade financiada exige licenciamento ambiental e, em caso afirmativo, requerer a apresentação da licença - informação inclusive, como foi exposto, acessível on-line em alguma medida. No mesmo compasso, parece que um nível mínimo de cuidado já recomenda que se consultem os órgãos ambientais acerca da existência de processos administrativos (em curso ou já concluídos) envolvendo a apuração ou punição de infrações de natureza ambiental. A pergunta é simples e a resposta também o é.

De outra parte, é forçoso concordar com o argumento de Annette Martinelli de Mattos Pereira quando esta defende que a adoção do regime da responsabilidade objetiva implicaria em que

[...] não haveria incentivo para as instituições financeiras adotarem medidas indutoras de boas práticas de proteção ambiental pelos responsáveis por projetos financiados se seus esforços nesse sentido não forem reconhecidos como capazes de desconstituir o nexo causal e afastar a responsabilização das instituições financeiras. (2017, p. $145)$.

De fato, seja mediante o reconhecimento da imprescindibilidade 
de culpa, que, a meu ver, não deve se limitar às situações de violação clara de normas, mas também abranger as situações de falhas operacionais - como, por exemplo, violação de normas internas da instituição ou mesmo normas internas inadequadas, desalinhadas das melhores práticas de mercado - e as situações em que a instituição descumpre compromissos aos quais ela se vinculou voluntariamente nessa matéria. Tal vínculo pode ser observado ante três situações, seja mediante o reconhecimento da existência de nexo de causalidade nessas mesmas situações - não é possível dar o mesmo tratamento, isto é, a responsabilização pelo dano ambiental causado pelo empreendimento financiado, qualquer que tenha sido o grau de diligência da instituição -, seja ao aprovar a operação ou investimento, seja ao monitorálo. É impossível ignorar que a instituição de um sistema de gestão de riscos socioambientais de qualidade no âmbito de uma instituição financeira ou investidor tem custos, requer tempo e estratégia para incorporar o assunto na cultura organizacional e adquirir a expertise necessária.

Não se pode deixar de reconhecer, por fim, o papel que um quadro regulatório mais claro teria para dar segurança e parâmetros que fortalecessem tais sistemas nas instituições financeiras e investidores em geral. Apenas para ilustrar, transcrevo as perguntas de Laurine D. Martins Lopes, que trabalhou nessa área para o maior banco privado brasileiro:

[...] quais as diligências socioambientais a serem adotadas? As diligências adotadas para a concessão de um empréstimo são as mesmas para o financiamento de um projeto? Em que casos se deve exigir licença ambiental? [...] Para operações cuja destinação dos recursos não pode ser previamente identificada pela instituição financeira, como é o caso do empréstimo, parece não fazer sentido a exigência de licença ambiental. Ainda tomando a Vale como exemplo, se por hipótese houvesse a obrigação de exigir licença para a concessão de empréstimo, qual das centenas de licenças a empresa deveria apresentar à instituição? Todas elas? (2017, p. 139).

Embora com relação a essa última pergunta a resposta seja muito simples quando a empresa só tem um estabelecimento, e, quando há vários, a solução possa ser simplesmente exigir a licença do estabelecimento que solicita o crédito (ou daquele onde se desenvolverá a atividade financiada), o fato é que o regulador deveria responder a estas questões. Essa mesma autora descreve o avanço de instituições bancárias brasileiras nessa temática e aponta que houve múltiplas causas para o fenômeno, referindose, em especial, ao papel do Judiciário, do Ministério Público e do Banco 
Central do Brasil (além da sociedade civil). Para ela,

[...] as instituições financeiras buscaram compreender as possíveis implicações da atuação efetiva desses agentes e, como resposta, adotaram medidas para se prevenirem do cenário de risco que aos poucos se delineava. A incorporação da variável socioambiental na análise de crédito ajudou a endereçar não só o risco de crédito que pudesse decorrer de uma operação que apresentasse problemas ou impactos socioambientais negativos, mas também os riscos de reputação, de mercado e até mesmo o risco legal relacionados à matéria. (2017, p. 138).

Isso tudo demonstra que uma atuação articulada entre as diversas partes interessadas no assunto é essencial e que o fortalecimento de sistemas de responsabilização pode e deve ser pensado de maneira a fortalecer em grau ainda maior os sistemas de prevenção de danos socioambientais.

\section{CONCLUSÕES}

Como busquei deixar claro ao longo do trabalho, muito mais do que dar nome à natureza jurídica da responsabilidade civil das instituições financeiras por danos ambientais (ou socioambientais) decorrentes das atividades econômicas por elas financiadas, é preciso detalhar parâmetros para que, em casos concretos, se possa avaliar se uma determinada instituição deve ou não ser considerada responsável, e em que medida, por dano social ou ambiental causado por empreendimento por ela financiado de alguma forma.

Procurei apontar nesse trabalho que parâmetros são esses. Embora se deva reconhecer a natureza subjetiva (e não objetiva) da responsabilidade de instituições financeiras nesses casos, já que ela decorre de omissões e não de ações, é preciso identificar quais são efetivamente as obrigações delas exigíveis que teriam, caso tivessem sido levadas a cabo, o condão de evitar a consumação do dano social ou ambiental, por tolher os recursos financeiros imprescindíveis ao desenvolvimento do empreendimento danoso. Por isso, apontei uma série de ferramentas, que já são inclusive adotadas pelas instituições financeiras mais avançadas em termos de responsabilidade ambiental, seja no Brasil, seja em mercados financeiros mais sofisticados que o nosso. 


\section{REFERÊNCIAS}

BLANK, Dionis Mauri Penning; BRAUNER, Maria Claudia Crespo. A responsabilidade civil ambiental das instituições bancárias pelo risco ambiental produzido por empresas financiadas. Revista eletrônica do Mestrado em Educação Ambiental. Universidade Federal do Rio Grande (FURG). Vol. 22. Jan-jul 2009, p. 261-275.

DAL MASO, David. Rischio ambientale e rischio creditizio. In: DAL MASO, Davide; BARTOLOMEO, Matteo (org.). Finanza e sviluppo sostenibile. Milano: Il Sole 24 Ore, 2001, p. 27-54.

GRIZZI, Ana Luci Esteves et alii. Responsabilidade civil ambiental dos financiadores. Rio de Janeiro: Lumen Juris, 2003.

ISIS Asset Management. A benchmarking study: environmental credit risk factors in the Pan-European Banking Sector. London: September 2002.

JEUCKEN, Marcel. Sustainability in Finance: banking on the planet. Delft: Eburon Academic Publishers, 2004.

LOPES, Laurine D. Martins. O processo de inserção da variável socioambiental na análise do crédito. In: YOSHIDA, Consuelo; PIAZZON, Renata; KISHI, Sandra; VIANNA, Marcelo Drügg Barreto (coord.). Finanças sustentáveis e a Responsabilidade socioambiental das instituições financeiras. Belo Horizonte: Fórum, 2017, p. 127-140.

MACHADO, Paulo Affonso Leme. Direito Ambiental Brasileiro. $12^{\mathrm{a}}$. ed. São Paulo: Malheiros, 2004.

NUSDEO, Ana Maria de Oliveira. Instituições financeiras e danos ambientais causados por atividades financiadas. In: YOSHIDA, Consuelo; PIAZZON, Renata; KISHI, Sandra; VIANNA, Marcelo Drügg Barreto (coord.). Finanças sustentáveis e a Responsabilidade socioambiental das instituições financeiras. Belo Horizonte: Fórum, 2017, p. 27-44.

RASLAN, Alexandre Lima. Responsabilidade civil ambiental do financiador. Porto Alegre: Livraria do Advogado, 2012. 
PELUCIO, Aline Pacheco. A análise econômica do Direito e a necessidade de definição de critérios objetivos para imputação da responsabilidade ambiental das instituições financeiras. In: YOSHIDA, Consuelo; PIAZZON, Renata; KISHI, Sandra; VIANNA, Marcelo Drügg Barreto (coord.). Finanças sustentáveis e a Responsabilidade socioambiental das instituições financeiras. Belo Horizonte: Fórum, 2017, p. 157-172.

PEREIRA, Annette Martinelli de Mattos. A responsabilidade civil ambiental das instituições financeiras e a Resolução CMN nº . 4.327/2014. In: YOSHIDA, Consuelo; PIAZZON, Renata; KISHI, Sandra; VIANNA, Marcelo Drügg Barreto (coord.). Finanças sustentáveis e a Responsabilidade socioambiental das instituições financeiras. Belo Horizonte: Fórum, 2017, p. 141-155.

SAMPAIO, Rômulo Silveira da Rocha. Responsabilidade civil ambiental das instituições financeiras. Rio de Janeiro: Campus-Elsevier/FGV, 2013.

SAMPAIO, Rômulo Silveira da Rocha; DINIZ, Érica; PORTO, Antonio José Maristrello; LOPES, Laurine D. Martins. Lenders and investors environmental liability: how much is too much? Working Paper for the UNEP Inquiry. Abril de 2016. Disponível em: <http://unepinquiry.org/wpcontent/uploads/2016/04/Lenders_and_Investors

Environmental_Liability.pdf> Acesso em 10 ago. 2016.

SOUZA, Luciane Moessa de. Sustentabilidade socioambiental no sistema financeiro: diagnóstico e propostas. Relatório de Pesquisa de PósDoutorado. Universidade de São Paulo (USP), abril de 2016.

UNITED NATIONS ENVIRONMENTAL PROGRAM (UNEP). Establishing China's Green FinancialSystem:detailed recommendations 13: Establish the Legal Liability of Financial Institutions. Inquiry: Design of a Sustainable Financial System. 2015. Disponível em: $<$ https:// www.cbd.int/financial/privatesector/china-ecgfs-13Lender\%20Liability. pdf $>$ Acesso em 5 jun. 2018.

YOSHIDA, Consuelo Yatsuda Moromizato. Responsabilidade das instituições financeiras: da atuação reativa à atuação proativa. In: 
OLIVEIRA, Carina Costa de; SAMPAIO, Rômulo Silveira da Rocha (orgs.). Instrumentos jurídicos para a implementação do desenvolvimento sustentável. Rio de Janeiro: Fundação Getulio Vargas, 2012, p. 115-134.

YOSHIDA, Consuelo Yatsuda Moromizato; PIAZZON, Renata S. Responsabilidade socioambiental dos bancos. Valor Econômico. São Paulo, 27 de maio de 2014.

Artigo recebido em: 28/06/2018. Artigo aceito em: 25/07/2018.

\section{Como citar este artigo (ABNT):}

SOUZA, L. M. RESPONSABILIDADE CIVIL DE INSTITUIÇÕES FINANCEIRAS POR DANOS SOCIOAMBIENTAIS. Veredas do Direito, Belo Horizonte, v. 15, n. 32, p. 357-396, ma./ago. 2018. Disponível em: $\quad<$ http://www.domhelder.edu.br/revista/index.php/veredas/article/ view/1302>. Acesso em: dia mês. ano. 